\title{
The Effect of C-Type Natriuretic Peptide on Delayed Rectifier Potassium Currents in Gastric Antral Circular Myocytes of the Guinea-Pig
}

\author{
H. Y. XU ${ }^{1,2}$, X. HUANG ${ }^{1}$, M. YANG ${ }^{2}$, J.-B. SUN ${ }^{2}$, L.-H. PIAO ${ }^{2}$, Y. ZHANG ${ }^{1}$, L. GAO ${ }^{1}$, \\ W.-X. XU ${ }^{1}$
}

${ }^{1}$ Department of Physiology, Medical College, Shanghai Jiaotong University, Shanghai, ${ }^{2}$ Department of Physiology, Yanbian University College of Medicine, Yanji, China

Received October 13, 2006

Accepted December 28, 2006

On-line available January 2, 2007

\begin{abstract}
Summary
C-type natriuretic peptides (CNP) play an inhibitory role in smooth muscle motility of the gastrointestinal tract, but the effect of CNP on delayed rectifier potassium currents is still unclear. This study was designed to investigate the effect of CNP on delayed rectifier potassium currents and its mechanism by using conventional whole-cell patch-clamp technique in guinea-pig gastric myocytes isolated by collagenase. CNP significantly inhibited delayed rectifier potassium currents $\left[I_{K}(v)\right]$ in dosedependent manner, and CNP inhibited the peak current elicited by depolarized step pulse to $86.1 \pm 1.6 \% \quad(n=7, P<0.05)$, $78.4 \pm 2.6 \%(n=10, P<0.01)$ and $67.7 \pm 2.3 \%(n=14, P<0.01)$, at concentrations of $0.01 \mu \mathrm{mol} / \mathrm{l}, \quad 0.1 \mu \mathrm{mol} / \mathrm{l}$ and $1 \mu \mathrm{mol} / \mathrm{l}$, respectively, at $+60 \mathrm{mV}$. When the cells were preincubated with $0.1 \mu \mathrm{mol} / / \mathrm{LY} 83583$, a guanylate cyclase inhibitor, the $1 \mu \mathrm{mol} / \mathrm{I}$ CNP-induced inhibition of $I_{K}(v)$ was significantly impaired but when the cells were preincubated with $0.1 \mu \mathrm{mol} / \mathrm{l}$ zaprinast, a cGMP-sensitive phosphodiesterase inhibitor, the $0.01 \mu \mathrm{mol} / \mathrm{l} \mathrm{CNP-}$ induced inhibition of $I_{K}$ (v) was significantly potentiated. 8-Br-cGMP, a membrane permeable cGMP analogue mimicked inhibitory effect of CNP on $I_{K}(v)$. CNP-induced inhibition of $I_{K}(v)$ was completely blocked by KT5823, an inhibitor of CGMPdependent protein kinase (PKG). The results suggest that CNP inhibites the delayed rectifier potassium currents via CGMP-PKG signal pathway in the gastric antral circular myocytes of the guinea-pig.
\end{abstract}

\section{Key words}

Delayed rectifier potassium currents $\bullet$ C-type natriuretic peptide • Gastric myocytes • Cyclic GMP

\section{Corresponding author}

Wen Xie Xu Department of Physiology, Medical College, Shanghai Jiaojtong University, 800 Dongchuan Rd., 328 Wenxuan Medical Building, Shanghai, 200240, China. E-mail: wenxiexu@sjtu.edu.cn

\section{Introduction}

Potassium currents represent the dominant repolarizing conductance within the physiological range of membrane potentials $(-50 \mathrm{mV}$ to $0 \mathrm{mV}$ ) and are critical in determining the membrane potential Em of smooth muscle cells. There is a general agreement that three kinds of outward potassium currents are in the smooth muscle cells (Kurgama et al. 1998), i.e. the delayed rectifier potassium currents $\left[I_{\mathrm{K}}(\mathrm{V})\right]$, the calciumactivated potassium currents $\left[I_{\mathrm{K}}\right.$ (ca) $]$ and the transient outward potassium currents $\left[I_{(\text {to })}\right]$. In our previous study, $I$ (to) was not observed in the gastric antral circular myocytes of the guinea-pig (Li et al. 2000, Piao et al. 2001). $I_{\mathrm{K}}(\mathrm{V})$ has already been characterized in various types of smooth muscle cells, for example, coronary artery (Leblanc et al. 1994), trachea (Boyle et al. 1992, Fleischmann et al. 1993), portal vein (Miller et al. 1993), cerebral artery (Albarwani et al. 2003) and pulmonary artery smooth muscle cells (Post et al. 1992, Wade et al. 1999), however, only a little has been done on $I_{\mathrm{K}(\mathrm{V})}$ in the gastrointestinal smooth muscle myocytes.

The functions of different types of potassium currents in smooth muscles are variable among different animals as well as among different organs. Wade et al (1999) identified a $I_{\mathrm{K}}(\mathrm{V})$ current and a $I_{\mathrm{K}}$ (ca) current in smooth muscle cells of human esophagus and demonstrated that $I_{\mathrm{K}}(\mathrm{V})$ current play a dominant role in regulation of resting tension of esophageal muscle, whereas $I_{\mathrm{K}}$ (ca) current largely limited contraction associated with excitation. Koh et al. (1998, 1999) 
observed the basal activation of ATP-sensitive potassium current $\left(I_{\mathrm{KATP}}\right)$ contributed to membrane potential in murine colonic smooth muscles and $I_{\text {KATP }}$ could contribute to dual regulation of membrane conductance and generate either depolarization or hyperpolarization, depending on the open probability of $I_{\text {KATP }}$ channels. However, $I_{(\mathrm{to})}$ contributed to the maintenance of negative resting membrane potentials in murine antral smooth muscle cells (Amberg et al. 2002).

C-type natriuretic peptide (CNP), a member of the natriuretic peptides family, was first isolated in porcine brain. It is a peptide of 22 amino acid residues including 17-residue sequences flanked by two cysteine residues which is common to all the natriuretic peptides (Sudoh et al. 1990). It is widely distributed and has been found in the central nervous system, cardiovascular system, digestive system, reproductive system, pulmonary system and almost all over the body (Barr et al. 1996). Natriuretic peptides elicit their physiological effects by binding to specific cell surface receptors, which have been denoted natriuretic peptide type A, B and $\mathrm{C}$ receptors (NPR-A, NPR-B and NPR-C). NPR-A preferentially binds atrial natriuretic peptide (ANP) and brain natriuretic peptide (BNP), whereas NPR-B is more selective for CNP (Misono 2002). NPR-A and NPR-B include intracellular particulate guanylyl cyclase (pGC) domains. Many facts have become available about the effect of CNP on $I_{\mathrm{K} \text { (ca) }}$ and its mechanism (Hiromi et al. 1994). CNP causes relaxation of vascular smooth muscle through activation of large-conductance calciumactivated potassium channels and activation of particulate and soluble guanylate cyclase (Banks et al. 1996). Inhibition of $\mathrm{Ca}^{2+}$-dependent potassium channels significantly attenuated human forearm vasodilation caused by CNP (Honing et al. 2001).

Our previous study demonstrated natriuretic peptide receptors were expressed in rat gastric smooth muscle (Guo et al. 2003a), and CNP induced relaxations of gastric smooth muscle in rat, guinea-pig and human (Guo et al. 2003b). The inhibitory effect of CNP on spontaneous contraction in guinea-pig was related to activation of large conductance calcium-activated potassium channels and activation of particulate guanylate cyclase (Guo et al. 2003c). However, the effect of CNP on $I_{\mathrm{K}}(\mathrm{v})$ and its mechanism is still unclear in gastric smooth muscle. Therefore, in this study we have investigated the effect of CNP on $I_{\mathrm{K}(\mathrm{V})}$ and the possibility of NPR-pGC-cGMP-PKG pathway involved in this process in guinea-pig gastric circular myocytes.

\section{Methods}

\section{Preparation of cells}

Single gastric myocytes were isolated enzymatically from the antrum of guinea pigs stomach, according to a protocol derived from the method as described previously (Xu et al. 1996). Briefly, EWG/B guinea pigs (obtained from the Experimental Animal Department of Jilin University College of Medicine, Certificate No. 10-6004) of either sex weighing 300-350 $\mathrm{g}$ were euthanized by lethal dose of pentobarbital sodium $(50 \mathrm{mg} / \mathrm{kg}$, i.p.). The antral part of the stomach was promptly excised and equilibrated in $\mathrm{Ca}^{2+}$-free physiological salt solution $\left(\mathrm{Ca}^{2+}\right.$-free PSS) which was oxygenated. After cutting out the mucosal layer using fine scissors, the muscle layer was separated and dissected into small segments $(1 \mathrm{~mm} \times 4 \mathrm{~mm})$. These segments were kept in modified Kraft-Bruhe (K-B) medium at $4{ }^{\circ} \mathrm{C}$ for $15 \mathrm{~min}$. Then they were incubated at $36{ }^{\circ} \mathrm{C}$ in $4 \mathrm{ml}$ digestion medium $\left(\mathrm{Ca}^{2+}\right.$-free $\left.\mathrm{PSS}\right)$ containing $0.1 \%$ collagenase Type II, $0.1 \%$ dithioerythreitol (DTT), $0.15 \%$ trypsin inhibitor and $0.2 \%$ bovine serum albumin (BSA) for 25-35 min. After digestion, the muscle segments were transferred into the modified K-B medium, and single myocytes were dispersed by gentle agitation with a wide-bored firepolished glass pipette. Isolated gastric antral myocytes were kept in modified K-B medium at $4{ }^{\circ} \mathrm{C}$ until use.

\section{Electrophysiological recordings}

The isolated myocytes were transferred to a small chamber on the stage of an inverted microscope (IX-70 Olympus, Japan) for 10-15 min and well-attached to the bottom of the chamber, then continuously superfused with PSS $(2-3 \mathrm{ml} / \mathrm{min})$. An 8-channel perfusion system (L/M-sps-8, List Electronics, Germany) was used to change the perfusate. Experiments were performed at $20-25{ }^{\circ} \mathrm{C}$ and the whole-cell configuration of the patch-clamp technique was applied. The patchclamp micropipettes were manufactured from borosilicate glass capillaries (GC) (150T-7.5, Clark Electromedical Instruments, UK) by a two-stage puller (PP-83, Narishige, Japan). Glass pipettes (2-5 M $\Omega$ ) filled with pipette solution were used to make giga seal of 3-5 G $\Omega$. Pipette and membrane capacitance and series resistance were electronically compensated and the whole-cell currents were recorded with a patch-clamp amplifier EPC-10 (HEKA Instruments, Germany). 
A

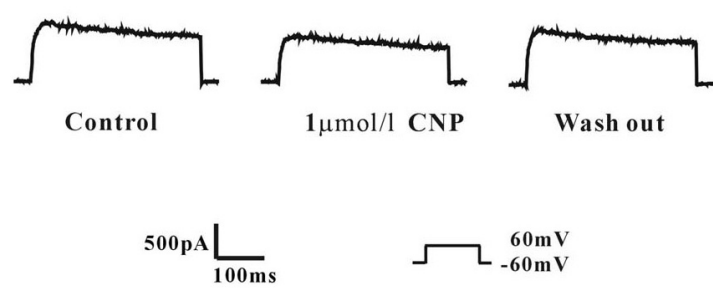

B

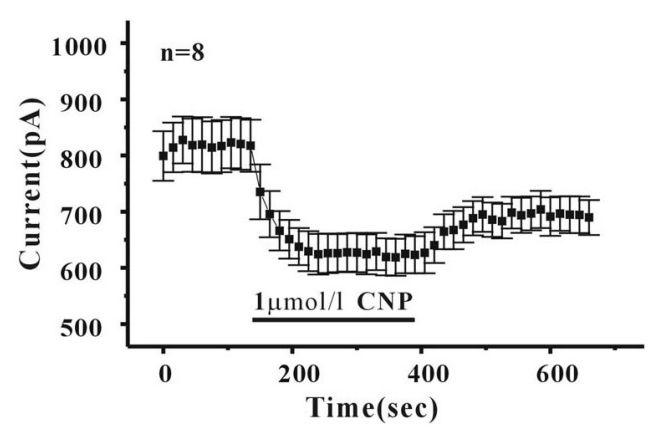

Fig. 1. Effect of CNP on $I_{K(V)}$ in the gastric antral circular myocytes. A shows raw current traces elicited by single depolarized step pulse. B shows the time-effect relationship of CNP on $I_{k(V)}$

\section{Drugs and solutions}

All drugs were purchased from Sigma Chemical Co, USA. Tyrode's solution contained $(\mathrm{mmol} / \mathrm{l}) \mathrm{NaCl}$ 147, $\mathrm{KCl} 4, \mathrm{CaCl}_{2} 2, \mathrm{MgCl}_{2} 1.05, \mathrm{NaH}_{2} \mathrm{PO}_{4} 0.42$, $\mathrm{Na}_{2} \mathrm{HPO}_{4} 1.81$ and glucose $5.5, \mathrm{pH}$ was adjusted to 7.35 with $\mathrm{NaOH}$. PSS contained (mmol/l) $\mathrm{NaCl} 134.8, \mathrm{KCl}$ 4.5, $\mathrm{MgCl}_{2}$ 1.0, $\mathrm{CaCl}_{2} 2.0$, glucose 5.0 and HEPES 10.0, and $\mathrm{pH}$ was adjusted to 7.4 by using Tris. In Ca-free PSS, $\mathrm{CaCl}_{2} 2.0 \mathrm{mmol} / \mathrm{l}$ was omitted from PSS. The $\mathrm{pH}$ of modified Kraft-Bruhe solution containing (mmol/l) egtazic acid 0.5, HEPES $10, \mathrm{MgCl}_{2} 3, \mathrm{KCl} 50$, glucose 10, L-glutamate 50, taurine 20 and $\mathrm{KH}_{2} \mathrm{PO}_{4}$ 20, was adjusted to 7.40 with $\mathrm{KOH}$. The pipette solution contained (mmol/l) potassium-aspartic acid 110, Mg-ATP 5, HEPES 5, $\mathrm{MgCl}_{2} 1.0, \mathrm{KCl} 20$, egtazic acid 10, di-triscreatine phoshate 2.5 and disodium-creatine phosphate 2.5, pH was adjusted to 7.30 with KOH. CNP, LY83583, zaprinast and KT5823 were prepared as $1 \mathrm{mmol} / \mathrm{l}$ stock solution respectively.

\section{Data analysis}

This experiment is substantiality for comparison. Control is the current before perfusion with CNP or other tool drugs. All values were expressed as mean \pm S.E.M. Statistical significance was evaluated by the $t$-test.
A

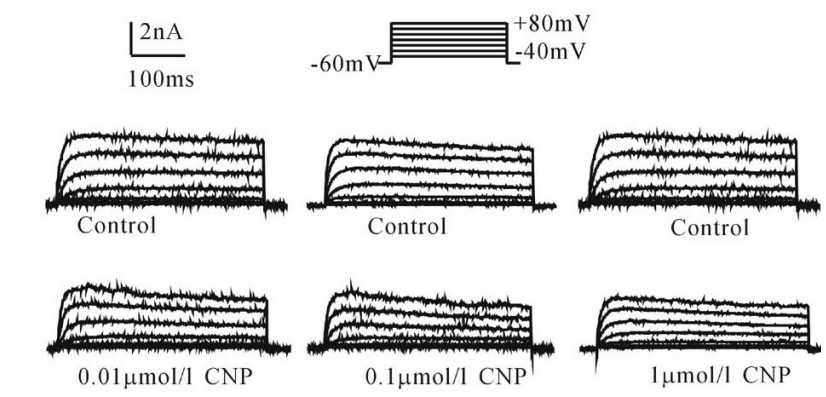

B

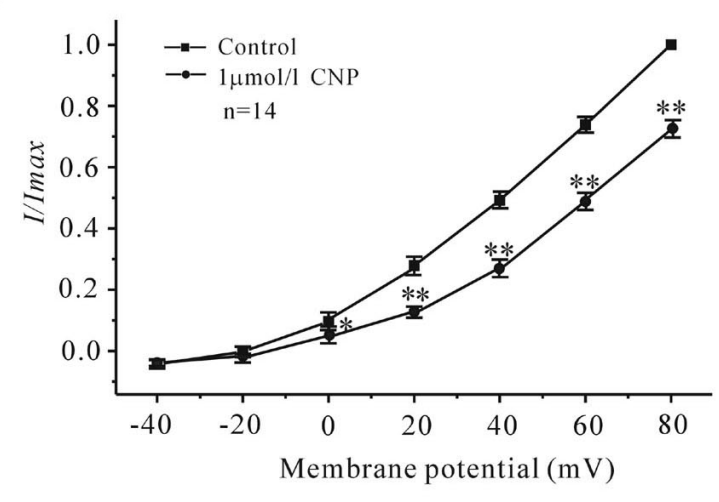

C

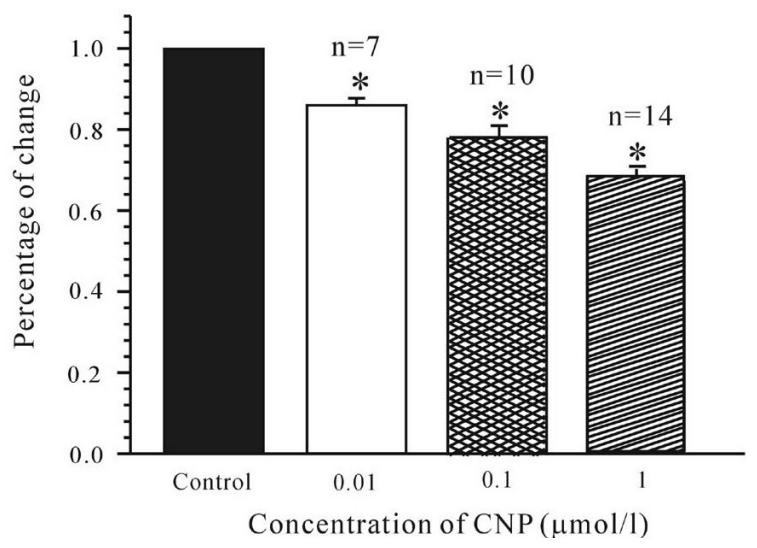

Fig. 2. Effect of different concentrations of CNP on $I_{\mathrm{K}(\mathrm{V})}$ in the gastric antral circular myocytes. A shows the raw current traces elicited by depolarizing step pulse. B shows I-V relation curve of $1 \mathrm{mmol} / \mathrm{L}$ CNP on $I_{\mathrm{K}(\mathrm{V})}$. C shows the dose-dependent inhibition of CNP on $I_{k(v)}$ at $+60 \mathrm{mV} .{ }^{*} P<0.05,{ }^{*} * P<0.01$ vs control group, respectively.

\section{Results}

Effect of CNP on $I_{K(V)}$

Delayed rectifier potassium currents were recorded from gastric antral myocytes by using conventional whole-cell patch-clamp technique in guinea pigs. Under the whole cell configuration, the membrane potential was clamped at $-60 \mathrm{mV}$, when the pipette solution contained egtazic acic $10 \mathrm{mmol} / \mathrm{l}, I_{\mathrm{K}}(\mathrm{v})$ was 
A

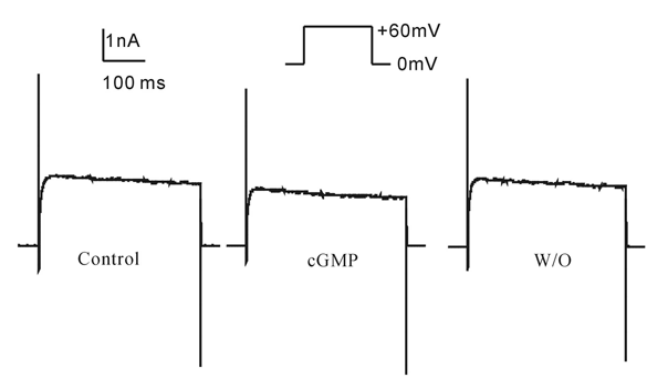

B

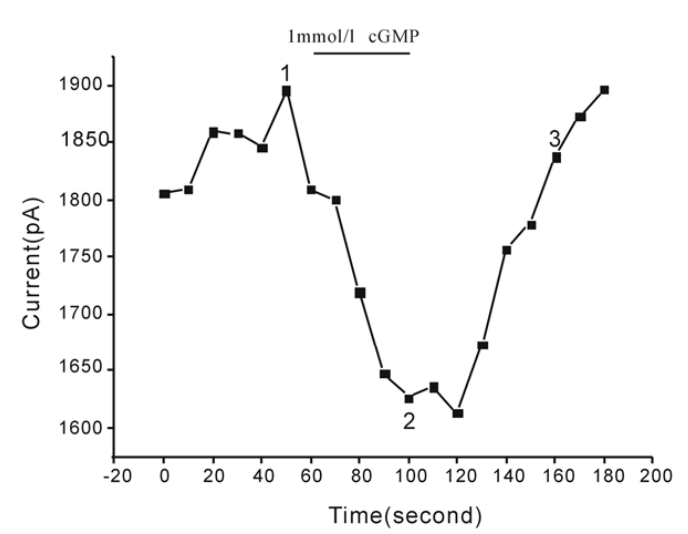

C

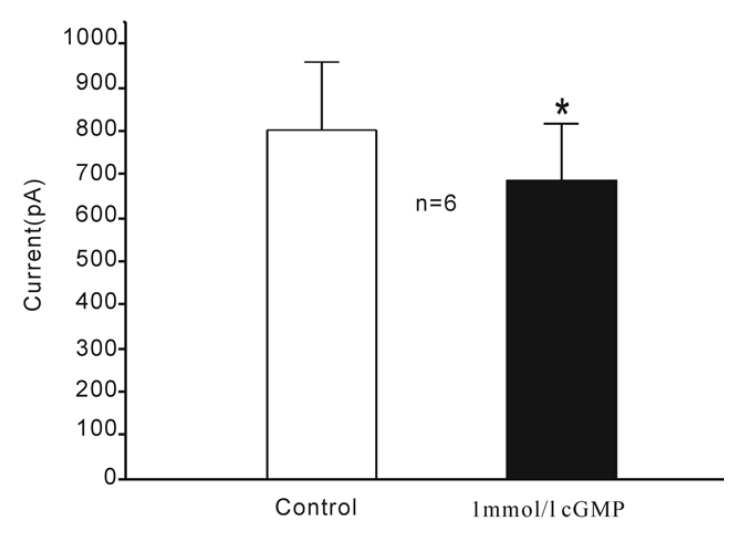

Fig.3. Effect of 8-Br-cGMP on $I_{\mathrm{K}(\mathrm{V})}$. A shows raw current traces elicited by single depolarized step pulse. B shows the time-effect relationship of $8-\mathrm{Br}-\mathrm{cGMP}$ on $I_{\mathrm{K}(\mathrm{V})}$, and $\mathbf{C}$ shows inhibitory effect of 8-Br-cGMP on $I_{k(v)}$ which summarized six cells.

elicited by step voltage command pulse from $-40 \mathrm{mV}$ to $+80 \mathrm{mV}$ for $440 \mathrm{~ms}$ with a $20 \mathrm{mV}$ increment at $10 \mathrm{sec}$ intervals. The mean peak current of $I_{\mathrm{K}}$ (V) was $921.8 \pm 33.5 \mathrm{pA} \quad \mathrm{n}=60$ at $+60 \mathrm{mV}$. First $I_{\mathrm{K}}$ (v) was elicited by a single depolarizing step pulse (depolarized to $+60 \mathrm{mV}, 15 \mathrm{sec}$ intervals) for $440 \mathrm{~ms}$, and observed the effect of CNP on $I_{\mathrm{K}}(\mathrm{V}) \cdot I_{\mathrm{K}}(\mathrm{V})$ was sharply suppressed by $1 \mu \mathrm{mol} / \mathrm{l} \mathrm{CNP}$, and the inhibitory effect started at $45 \mathrm{sec}$ after cells were exposed to CNP (Fig. 1). The inhibitory effect of CNP on $I_{\mathrm{K}(\mathrm{V})}$ was partially recovered after CNP was washed out (Fig. 1B). Using the same pulse protocol,
A

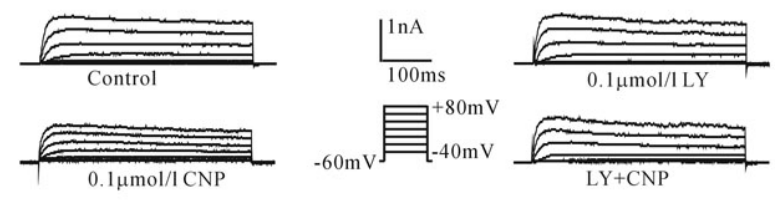

B
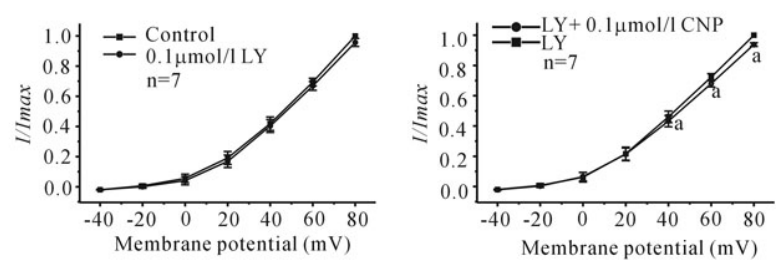

C

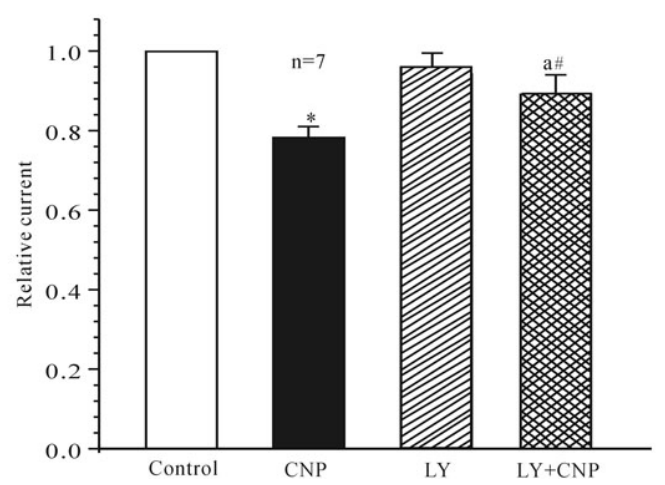

Fig.4. Effect of LY83583 on CNP-induced inhibition of $I_{\mathrm{k}(\mathrm{V})}$. A shows the raw current traces elicited by depolarizing step pulse. $B$ shows the I-V relationships and C shows the effect of LY83583 on CNP-induced inhibition of $I_{\mathrm{K}(\mathrm{V})}$ at $+60 \mathrm{mV} .{ }^{*} P<0.01 \mathrm{vs}$ control group, a $P<0.05$ vs LY83583 group, ${ }^{\#} P<0.05$ vs CNP group, respectively.

the effect of different concentrations of CNP on $I_{\mathrm{K} \text { (V) was }}$ observed. CNP significantly inhibited $I_{\mathrm{K}}(\mathrm{V})$ in a dosedependent manner (Fig. 2A), and $I_{\mathrm{K}}$ (V) values was significantly decreased by $1 \mu \mathrm{mol} / \mathrm{l} \mathrm{CNP}$ at every membrane potential from $0 \mathrm{mV}$ to $+80 \mathrm{mV}$ in I-V curve (Fig. 2B, n=14, $\mathrm{P}<0.01$ ). CNP-induced inhibitions of $I_{\mathrm{K}}$ (V) from $100 \%$ of control suppressed to $86.1 \pm 1.6 \%$ ( $n=7$, $\mathrm{P}<0.05), 78.4 \pm 2.6 \%(\mathrm{n}=10, \mathrm{P}<0.01)$ and $67.7 \pm 2.3 \%$ $(\mathrm{n}=14, \quad \mathrm{P}<0.01) \quad$ at concentrations of $0.01 \mu \mathrm{mol} / \mathrm{l}$, $0.1 \mu \mathrm{mol} / 1$ and $1 \mu \mathrm{mol} / 1$, respectively, at $+60 \mathrm{mV}$ (Fig. 2C).

\section{Effect of 8-Br-cGMP on $I_{K(V)}$}

Since CNP can bind with NPR-B and activate pGC we investigated whether the inhibitory effect of CNP on $I_{\mathrm{K}(\mathrm{V})}$ is mediated by cGMP. The result showed that cell membrane permeable 8-Br-cGMP mimicked the 
A

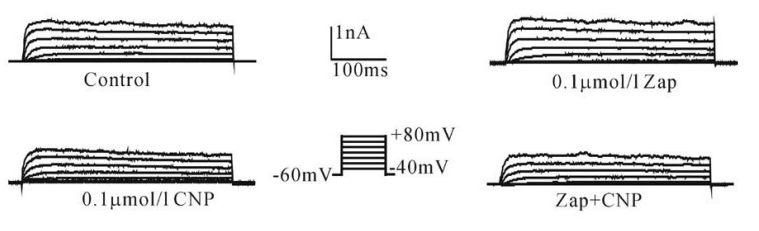

B
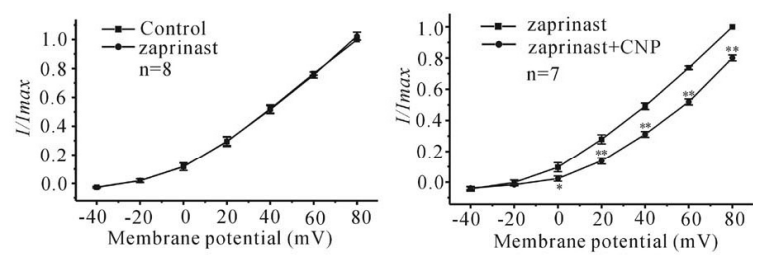

C

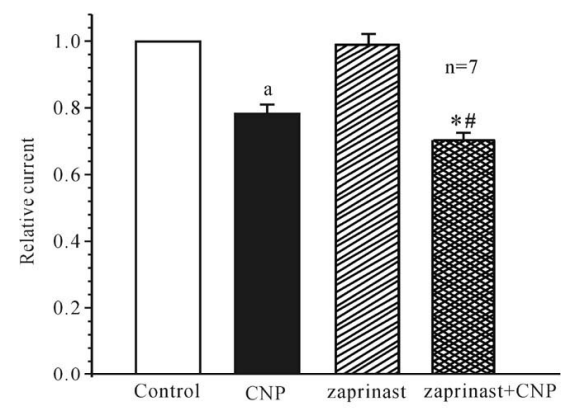

D

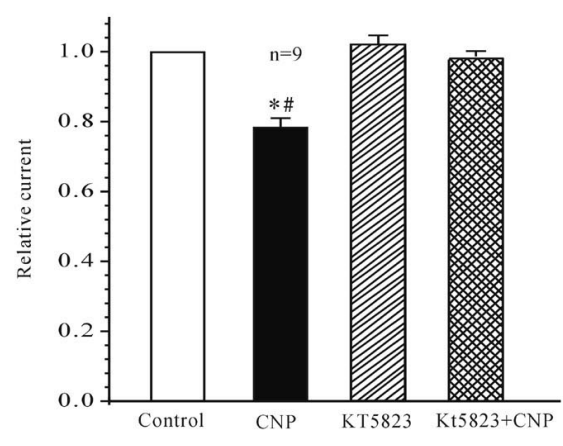

Fig 5. Effects of zaparinast and KT5823 on CNP-induced inhibition of $I_{k(v)}$. A shows the raw current traces elicited by depolarizing step pulse. B shows the I-V relationships and C shows the effect of zaparinast on CNP-induced inhibition of $I_{K(V)}$ at $+60 \mathrm{mV}\left({ }^{\mathrm{a}} P<0.01\right.$ vs Control group; ${ }^{*} P<0.05,{ }^{*} P<0.01$ vs zaparinast group; ${ }^{\#} P<0.01$ vs CNP group respectively). D shows the effect of KT5823 on CNP-induced inhibition of $I_{K(V)}$ at $+60 \mathrm{mV}$ ( ${ }^{*} P<0.01$ vs Control group, ${ }^{\#} P<0.01$ vs CNP group respectively).

inhibitory effect of CNP, and $1 \mathrm{mmol} / 1$ 8-Br-cGMP suppressed $I_{\mathrm{K}}(\mathrm{V})$ from $801.8 \pm 224.8 \mathrm{pA}$ of control to $686.3 \pm 193.5$ pA (Fig. 3, $\mathrm{n}=6, \mathrm{P}<0.05$ ).

\section{Effect of LY83583, zaprinast on CNP-induced inhibition of $I_{K(V)}$}

To further investigate the relationship between
cGMP and inhibitory effect of CNP on $I_{\mathrm{K}}(\mathrm{V})$, in the presence of LY83583, a guanylate cyclase inhibitor or zaprinast, a cGMP-sensitive phosphoesterase inhibitor conditions CNP-induced inhibition of $I_{\mathrm{K}}(\mathrm{V})$ was observed. LY83583 itself $(0.1 \mu \mathrm{mol} / \mathrm{l})$ had no effect on $I_{\mathrm{K}}(\mathrm{V})$ (Figs 4A and 4B, $\mathrm{n}=7, \quad \mathrm{P}>0.05$ ), but LY83583 significantly diminished the inhibitory effect of CNP on $I_{\mathrm{K}}(\mathrm{V})$ in gastric antrial myocytes (Figs $4 \mathrm{~A}$ and $4 \mathrm{~B}, \mathrm{n}=7$, $\mathrm{P}<0.05$ ). The inhibitory percentage of CNP on $I_{\mathrm{K}}(\mathrm{V})$ was diminished from $78.4 \pm 2.6 \%$ of control to $89.5 \pm 4.5 \%$ by LY83583 at $+60 \mathrm{mV}$ (Fig. $4 \mathrm{C}, \mathrm{n}=7, \mathrm{P}<0.05$ ). However, zaprinast significantly potentiated CNP-induced inhibition of $I_{\mathrm{K}}(\mathrm{V})$ (Figs $5 \mathrm{~A}$ and $5 \mathrm{~B}$ ), and the inhibitory percentage of $\mathrm{CNP}$ on $I_{\mathrm{K}}(\mathrm{V})$ was potentiated from $78.4 \pm 2.6 \%$ of control to $70.3 \pm 2.2 \%$ at $+60 \mathrm{mV}$ (Fig. $5 \mathrm{C}$, $\mathrm{n}=7, \mathrm{P}<0.05)$.

\section{Effect of PKG inhibitor on CNP-induced inhibition of $I_{K(V)}$}

Since the inhibitory effect of CNP on $I_{\mathrm{K}}(\mathrm{V})$ was related to cGMP, we further determined whether this process was mediated by cGMP-dependent protein kinase (PKG). The CNP-induced inhibition of $I_{\mathrm{K}}$ (V) was completely blocked by $1 \mu \mathrm{mol} / 1 \mathrm{KT} 5823$, an inhibitor of PKG (Fig.6, n=9, P<0.01).

\section{Discussion}

The effects of CNP on the gastrointestinal motility have been described by only some reports relaxant effect on chick rectum muscle strip (Sudoh et al. 1990), inhibitory effect on rat tenia coli (Kim et al. 2001), and relaxant effect on guinea-pig caecum (Itaba et al. 2004). We demonstrated that CNP inhibited spontaneous contractions of gastric smooth muscles in rat, guinea-pig and human (Guo et al. 2003b), and hyperpolarized membrane potential in guinea-pig gastric smooth muscle and potentiated calcium-activated potassium currents $\left[I_{\mathrm{K}}\right.$ (Ca)] (Guo et al. 2003c). Much evidence indicated that $I_{\mathrm{K}}$ (Ca) is involved in inhibitory effects of CNP on smooth muscle motility. For example, CNP mediated the relaxation of canine femoral veins through activation of large conductance calcium-activated potassium channels $\left(\mathrm{BK}_{\mathrm{Ca}}\right)$ and activation of particulate and soluble guanylate cyclase (Banks et al. 1996). Inhibition of $\mathrm{Ca}^{2+}$-dependent potassium channels significantly attenuated human forearm vasodilation caused by CNP (Honing et al. 2001).

In the present study, however, it was found that 
CNP significantly inhibited $I_{\mathrm{K}}(\mathrm{V})$ in a dose-dependent manner. Since CNP hyperpolarized membrane potential of gastric myocytes, it is suggested that the total effect of CNP on gastric smooth muscle is the increase of the outward potassium currents and relaxing smooth muscles, and CNP-induced relaxation is mainly mediated by $I_{\mathrm{K}(\mathrm{Ca}) \text {. }}$. Many studies support our standpoint, because the dual regulation by $\mathrm{Ca}^{2+}$ and voltage allowed $\mathrm{BK}_{\mathrm{Ca}}$ channels to play a more dynamic role in the regulation of cellular excitability than is possible with strictly voltage-gated $\mathrm{K}^{+}$ channel homologues (Lingle et al. 2002), $I_{\mathrm{K}}(\mathrm{V})$ current appeared to play a dominant role in regulation of resting tension of human esophageal muscle, whereas $I_{\mathrm{K}}$ (Ca) current largely limited contraction associated with excitation (Wade et al. 1999), Otsuka et al (2002) found that the apparent extent of $\mathrm{BK}_{\mathrm{Ca}}$ channels contributing to the total CNP-induced relaxant response was $\approx 60 \%$, supporting the substantial role of $\mathrm{BK}_{\mathrm{Ca}}$ channels in the CNP-induced vascular relaxations (Otsuka et al. 2002). According to previous study and our results, $I_{\mathrm{K}(\mathrm{V})}$ might play a dominant role in regulation of resting membrane potential in gastric antral circular myocytes of guinea-pig, whereas $I_{\mathrm{K}}$ (Ca) may regulate the relaxation in response to the changes of $\left[\mathrm{Ca}^{2+}\right]_{\mathrm{i}}$ caused by inner or outer stimulations.

Many studies demonstrated that CNP exerted a physiological function throuogh cGMP pathway. It was found that cGMP increased twofold within 10-60 s after the addition of CNP (Banks et al. 1996). ANP, BNP and CNP induce the relaxation of the vascular smooth muscle via particulate guanylate cyclase (GC) which produces cGMP (Winquist et al. 1984, Protter et al. 1996, Akiho et al. 1995). Basal release of cGMP was increased up to 4-fold by CNP and this increase was reduced (-68\%) in presence of the natriuretic peptide receptor (NPR) antagonist HS-142-1 (Brunner et al. 2001). We previously reported that CNP significantly enhanced cGMP generation in rat gastric smooth muscle (Guo et al. 2003a). In the present study, 8-Br-cGMP mimicked inhibitory effect of CNP on $I_{\mathrm{K}}(\mathrm{V})$ and LY83583, a kind of inhibitor of guanylate cyclase, markedly diminished the inhibitory effect of CNP on $I_{\mathrm{K}}(\mathrm{V})$, but zaprinast, a cGMPsensitive phosphodiesterase inhibitor, significantly potentiated the CNP-induced inhibition of $I_{\mathrm{K}}(\mathrm{V})$. These data suggested that the CNP-induced inhibition of $I_{\mathrm{K}}(\mathrm{V})$ was mediated by CNP-NPR-pGC-cGMP pathway. Meanwhile, KT5823, an inhibitor of cGMP-dependent protein kinase (PKG), completely blocked the CNPinduced inhibition of $I_{\mathrm{K}}(\mathrm{V})$. This suggests that cGMPPKG pathway was involved in this process. Similarly, Zhang et al (2003) found that cGMP inhibited $I_{\mathrm{K}}(\mathrm{v})$ in both hypoxic and normal rat pulmonary artery smooth muscle cells, and this inhibition was blocked by H-8, an inhibitor of PKG.

In summary, the major findings from this investigation were that CNP inhibited $I_{\mathrm{K}}(\mathrm{V})$ in a dosedependant manner and the cGMP-PKG pathway was involved in this process in guinea-pig gastric antral circular myocytes. $I_{\mathrm{K}}(\mathrm{V})$ may play a dominant role in regulating resting membrane potential in the gastric antral circular myocytes of guinea-pigs.

\section{Conflict of Interest}

There is no conflict of interest.

\section{Acknowledgements}

Supported by the National Natural Science Foundation of China, No 30160028, 30360031.

\section{References}

AKIHO H, CHIJIIWA Y, OKABE H, HARADA N, NAWATA H: Interaction between atrial natriuretic peptide and vasoactive intestinal peptide in guinea pig cecal smooth muscle. Gastroenterology 109: 1105-1112, 1995.

ALBARWANI S, NEMETZ LT, MADDEN JA, TOBIN AA, ENGLAND SK, PRATT PF, RUSCH NJ: Voltage-gated $\mathrm{K}+$ channels in rat small cerebral arteries: molecular identity of the functional channels. $J$ Physiol Lond 551: 751-763, 2003.

AMBERG GC, BAKER SA, KOH SD, HATTON WJ, MURRAY KJ, HOROWITZ B, SANDERS KM: Characterization of the A-type potassium current in murine gastric antrum. J Physiol Lond 544: 417-128, 2002.

BANKS M, WEI CM, KIM CH, BURNETT JC Jr, MILLER VM: Mechanism of relaxations to C-type natriuretic peptide in veins. Am J Physiol 271: H1907-H1911, 1996.

BARR CS, RHODES P, STRUTHERS AD: C-type natriuretic peptide. Peptides 17: 1243-1251, 1996.

BOYLE JP, TOMASIC M, KOTLIKOFF MI: Delayed rectifier potassium channels in canine and porcine airway smooth muscle cells. J Physiol Lond 447: 329-350,1992. 
BRUNNER F, WOLKADRT G: Relaxant effect of C-type natriuretic peptide involves endothelium and nitric oxidecGMP system in rat coronary microvasculature. Cardiovasc Res 51: 577-584, 2001.

FLEISCHMANN BK, WASHABU RJ, KOTLIKOFF MI: Control of resting membrane potential by delayed rectifier potassium currents in ferret airway smooth muscle cells. $J$ Physiol Lond 469: 625-638,1993.

GUO HS, CUI X, CUI YG, KIM SZ, CHO KW, LI ZL, XU WX: Inhibitory effect of C-type natriuretic peptide on spontaneous contraction in gastric antral circular smooth muscle of rat. Acta Pharmacol Sin 24: 1021-1026, $2003 b$.

GUO HS, JIN Z, JIN ZY, LI ZH, CUI YF, WANG ZY, XU WX: Comparative study in the effect of C-type natriuretic peptide on gastric motility in various animals. World J Gastroenterol 9: 547-552, 2003a.

GUO HS, CAI ZX, ZHENG HF, LI XL, CUI YF, WANG ZY, XU WX, LEE SJ, KIM YC: Role of calcium-activated potassium currents in CNP-induced relaxation of gastric antral circular smooth muscle in guinea pigs. World $J$ Gastroenterol 9: 2054-2059, 2003c.

HIROMI H, HAJIME S, MAKOTO I, TAKANOBU Y, MAYUMI F, SHOJI T, SHIGEHISA H: Autocrine regulation of rat chondrocyte proliferation by natriuretic peptide $\mathrm{C}$ and its receptor, natriuretic peptide receptor-B. $J$ Biol Chem 269: 10729-10733, 1994.

HONING ML, SMITS P, MORRISON PJ, BURNETT JC Jr, RABELINK TJ: C-type natriuretic peptide-induced vasodilation is dependent on Hyperpolarization in human forearm resistance vessels. Hypertension 37: 1179$1183,2001$.

ITABA S, CHIJIIWA Y, MATSUZAKA H, MOTOMURA Y, NAWATA H: Presence of C-type natriuretic peptide (CNP) in guinea pig caecum: role and mechanisms of CNP in circular smooth muscle relaxation. Nurogastroenterol Motil 16: 375-382, 2004.

KIM JH, JEON GH, KIM SZ, CHO KW, KIM SH: C-type natriuretic peptide system in rabbit colon. Peptides 22: 2061-2068, 2001.

KOH SD, WARD SM, DICK GM, EPPERSON A, BONNER HP, SANDERS KM, HOROWITZ B, KENYON JL: Contribution of delayed rectifier potassium currents to the electrical activity of murine colonic smooth muscle. J Physiol Lond 512: 475-487, 1999.

KOH SD, WBRADLEY KK, RAE MG, KEEF KD, HOROWITZ B, SANDERS KM: Basal activation of ATPsensitive potassium channels in murine colonic smooth muscle cell. Biophys $J$ 75: 1793-1800, 1998.

KURGAMA H, KITAMURA K, ITOH T, INOUE R: Physiology features of visceral smooth muscle cells, with special reference to receptors and ion channels. Physiol Rev 78: 812-889, 1998.

LEBLANC N, WAN X, LEUNG PM: Physiological role of $\mathrm{Ca}^{2+}$-activated and voltage-dependent $\mathrm{K}^{+}$currents in rabbit coronary myocytes. Am J Physiol 266: C1523-C1537, 1994.

LI Y, XU WX, LI ZL: Effect of nitroprusside,3-morpholinosydnonimine, and spermine on calcium-sensitive potassium currents in gastric antral circular myocytes of guinea pig. Acta Pharmacol Sin 21:571-576, 2000.

LINGLE CJ: Setting the stage for molecular dissection of the regulatory components of BK channels. $J$ Gen Physiol 120: 261-265, 2002.

MILLER AL, MORALES E, LEBLANC NR, COLE WC: Metabolic inhibition enhances $\mathrm{Ca}^{2+}$-activated $\mathrm{K}^{+}$currents in smooth muscle cells of rabbit portal vein. Am J Physiol 265: H2184-H2195, 1993.

MISONO KS: Natriuretic peptide receptor: structure and signaling. Mol Cell Biochem 230: 49-60, 2002.

OTSUKA K, TANAKA H, HORINOUCHI T, KOIKE K, SHIGENOBU K, TANAKA Y: Functional contribution of voltage-dependent and $\mathrm{Ca}^{2+}$ activated $\mathrm{K}^{+}\left(\mathrm{BK}_{\mathrm{Ca}}\right)$ channels to the relaxation of guinea-pig aorta in response to natriuretic peptides. J Smooth Muscle Res 38: 117-129, 2002.

PIAO L, LI Y, LI L, XU WX: Increment of calcium-activated and delayed rectifier potassium current by hyposmotic swelling in gastric antral circular myocytes of guinea pig. Acta Pharmacol Sin 22: 566-572, 2001.

POST JM, HUME JR, ARCHER SL, WEIR EK: Direct role for potassium channel inhibition in hypoxic pulmonary vasoconstriction. Am J Physiol 262: C882-C890, 1992.

PROTTER AA, WALLACE AM, FERRAIS VA, WEISHAAR RE: Relaxant effect of human brain natriuretic peptide on human artery and vein tissue. Am J Hypertens 9: 432-436, 1996. 
SUDOH T, MINAMINO N, KANGAWA K, MATSUO H: C-type natriuretic peptide (CNP): a new member of natriuretic peptide family identified in porcine brain. Biochem Biophys. Res Commun 168: 863-870, 1990.

WADE GR, LAURIER LG, PREIKSAITIS HG, SIMS SM: Delayed rectifier and $\mathrm{Ca}^{2+}$-dependent $\mathrm{K}^{+}$currents in human esophagus: roles in regulating muscle contraction. Am J Physiol 277: G885-G895, 1999.

WINQUIST RJ, FAISON EP, WALDMAN SA, SCHWARTZ K, MURAD F, RAPOPORT RM: Atrial natriuretic factor elicits an endothelium-independent relaxation and activates particulate guanylate cyclase in vascular smooth muscle. Proc Natl Acad Sci USA 81: 7661-7664, 1984.

XU WX, KIM SJ, SO I, KANG TM, KIM KW: Effect of stretch on calcium channel currents recorded from the antral circular myocytes of guinea-pig stomach. Pflugers Arch 432: 159-164, 1996.

ZHANG YC, NI W, ZHEN GH, ZHANG ZX, XU YJ: Effect of cGMP on voltage-gated potassium channel in pulmonary artery smooth muscle cells from rats exposed to chronic hypoxia. Chin J Pathophysiol 19: 1012$1015,2003$. 